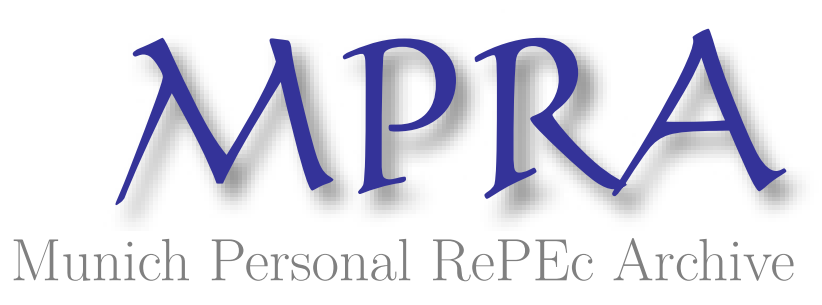

\title{
Contesting digital finance for the poor
}

\author{
Ozili, Peterson K
}

2020

Online at https://mpra.ub.uni-muenchen.de/101812/

MPRA Paper No. 101812, posted 15 Jul 2020 09:30 UTC 


\title{
Contesting digital finance for the poor
}

\author{
Peterson K. Ozili
}

\begin{abstract}
This article critically examines digital finance as a pro-poor private sector intervention for international development. It examines the turn from 'microfinance for the poor' to 'digital finance for the poor'. It then considers three key issues, and contest the argument that digital finance is pro-poor. Notably, proponents argue that digital finance can improve development outcomes, but this is based on weak economic logic; secondly, proponents argue that digital finance for the poor is good business - this claim is very weak because evidence suggest that digital finance is good business only with government support. The article further argues that digital finance for the poor will expose the poorest to multiple risks in the financial sector. Therefore, digital finance for the poor should be a contested enterprise.
\end{abstract}

Keywords: digital finance, microfinance, financial inclusion, financial development, financial innovation, poor people, financial technology, blockchain, fintech, regtech, sandbox, access to finance, financial services

JEL Code: E5, G2, O16, G21, G28.

May, 2020.

Acknowledgement: This paper has benefitted substantially from the ideas in a 2018 paper 'Contesting financial inclusion' written by Philip Mader of the Institute of Development Studies. 


\section{Introduction}

This paper contests digital finance for the poor. This paper builds on Mader (2018)'s paper by linking digital finance to the broader financial inclusion agenda, and then criticize the delivery of digital finance to poor people in the risky financial sector.

Today, digital finance has been endorsed by the international development finance community as a success factor to achieve global financial inclusion (Banks, 2001; Gabor and Brooks, 2017; Figueiredo et al, 2012). But what is digital finance? Digital finance is financial services delivered through mobile phones and computer networks linked to a reliable payment system (Gabor and Brooks, 2017; Ozili, 2018). In recent years, big corporations and technologists lobby governments to formulate policies that compel economic agents to use digital finance products and digital platforms to make payments such as the payment of employee salaries and other large transactions, and they also lobby for lower digital tax payments. These corporate lobbyists influence policy makers to formulate and enforce policies that encourage the use of digital payment channels ${ }^{12}$, such as imposing fees for large cash withdrawals to discourage cash transactions which will compel individuals and poor households to use available digital finance products to perform day-to-day transactions and large transactions rather than using physical cash, which they claim will help to achieve financial inclusion. These practices show that policy makers can be easily swayed by private interests which also creates a business opportunity for technologists and financial institutions - it creates an opportunity for them to make profit from serving customers including poor customers.

But the eagerness of big corporations, banks, technologists, capitalists and lobbyists to deliver digital finance products to poor people under the guise of promoting financial inclusion raises to two big questions: what's in it for them? And why the poor in particular? The first question relates to whether 'digital finance for the poor' makes a good business sense while the second question relates to whether digital finance actually improves or deteriorate the financial welfare of poor people. In this paper, I argue that the formal financial sector is inherently risky, and bringing poor people into the financial sector would expose them to systematic risks in the financial sector. Poor people have little money, and the intense eagerness of banks and technology companies to deal with poor people is worrisome (Mader, 2018), because using digital finance to bring poor people into the formal financial sector through digital finance products will expose poor people to risks associated with doing business with banks, other financial institutions and technology companies. An example of the inherent risk in the financial sector is the risk associated with deposits and stocks. For instance, your deposits in a bank is at risk because banks can fail. Your investments in stocks are at risk because companies can make losses and may even go bankrupt leading to loss of dividends. Your ability to perform digital financial transactions is also at risk because digital infrastructures can fail due to network connectivity problems, software and hardware issues.

While these risks cannot be avoided or eliminated completely from the formal financial sector at least for now, the collective rush to bring the poor into the risky formal financial sector raises a lot of critical issues and questions which are often overlooked, such as: does 'digital finance for the poor' really promote development in finance? do poor people benefit in meaningful ways from using digital financial services? If yes, are the benefits to the poor greater than the risks or costs to the poor? does digital finance reduce or amplify the existing risks in the formal financial sector? does digital finance

\footnotetext{
${ }^{1}$ https://www.chinadaily.com.cn/a/202001/08/WS5e153f85a310cf3e355832a4.html

${ }^{2}$ https://www.laserfiche.com/ecmblog/how-technology-companies-lobby-federal-government/
} 
expose the poor to greater risk than they can handle? And finally, does digital finance for the poor make good business sense? The answer to these questions are not straightforward yet the digital finance "movement" represented by think-tanks, corporate promoters and lobbyists like Visa, MasterCard Foundation and funders like the World Bank and the International Monetary Fund (IMF) generally provide positive answers to these questions at least in their public pronouncements while failing to emphasize the weaknesses of digital finance for the poor.

Using critical policy discourse analysis, I explain the turn from "micro finance" to "digital finance", and thereafter, I discuss four issues: the lack of evidence that digital finance for poor people actually promotes socio-economic development; the risks that poor people are exposed to which arises from their exposure to digital finance technology; the lack of evidence that digital finance actually brings poor people immediate benefits; and the weak business rationale for digital finance. I challenge the emerging development advocacy for 'digital finance for the poor' serving as a core pro-poor private sector-led development intervention, and argue that 'digital finance for the poor' itself is a contested and contestable enterprise because currently there is insufficient evidence for 'digital finance for the poor' being development-promoting, poverty-alleviating, and profitable enough, to justify all the attention and resources directed toward it. As branch banking and microfinance gradually gives way to digital finance, a major re-evaluation of the developmental and business logic of digital finance for the poor is urgently needed.

This article is distinct from the studies that examine the role of microfinance, microcredit and financial innovation in increasing the level of financial inclusion. Such studies, for instance, Cabraal et al (2006) show that microfinance is an important strategy for poverty alleviation, and Brown et al (2015) show that closeness to a microfinance bank significantly improves the level of financial inclusion through expansion in branch network. Ozili (2018) show that digital finance has benefits for financial inclusion and also highlight the complex issues in using digital finance to promote financial inclusion. Domeher et al (2014) find evidence that adopting financial innovation in the banking sector can increase the likelihood of adopting e-banking products and services for greater financial inclusion. Taken together, these studies argue that the availability of microcredit, microfinance and financial innovation such as digital finance products can improve financial inclusion and increase the level of entrepreneurial and economic activities. In contrast, studies such as Hembruff and Soederberg (2019) show that payday lenders, a type of micro-finance lenders, not only benefit at the expense of the poor people through their expensive loans, they also create a lending system that make poor people dependent on such loans to meet their basic needs. Mader and Sabrow (2019) argue that the recent shift from microfinance to financial inclusion lacks an underlying rational innovation for poverty alleviation and is at best a myth. Also, the financial inclusion debate does not take into account how inequality affects financial inclusion through its detrimental impact on the level of financial development (Gwama, 2014). This paper is distinct from the above studies in that its argue that all digital finance systems should be de-risked before bringing financial technology to poor people who are economically vulnerable. The argument here is not that 'digital finance for the poor' is harmful or undesirable or destined to fail; rather, the argument points to the need to de-risk the digital finance infrastructure and to de-risk the digital financial system for the benefit of poor people. This article is also distinct from other studies in that it examines how technology in finance affect people in different socioeconomic status particularly the poor.

This article contributes to the literature in four ways. One, this study contributes to the digital finance literature. Previous studies identify several risk and challenges of digital finance such as the risks of service disruption, loss of data, privacy risks due to the large number of agents required to process client 
data, security risk arising from the digital transmission and storage of data (see Ozili, 2018; Hu and Zheng, 2016). This study adds to the literature by critically analyzing the risks associated with using digital finance products and platforms, and to challenge its acclaimed pro-poor cause. It also adds to the literature by showing that the use of digital finance products and infrastructure can be too risky for poor people, and emphasize the need to de-risk the digital finance system and infrastructure before bringing it to poor people.

Two, the study contributes to the literature that examine how economic activities affect social processes (see Hakim, 2012; Barr, 2012; Benhabib et al, 2010; Von Wieser, 2013; Schotter, 2008; Hellmich, 2017). These studies analyze how societies progress, stagnate, or regress because of their local or regional economy under different contexts. This study contributes to this literature by showing that the effectiveness of using digital finance to improve people's welfare depends on the socioeconomic status of the beneficiaries and their willingness to adopt financial technology especially for poor people, bearing in mind that poor and uneducated people are often affected disproportionately compared to rich and educated people. Three, it contributes to the on-going policy discourse that promote digital finance as an effective solution for financial inclusion in emerging and poor countries (e.g., Banks, 2001; Barbesino et al, 2005, Ozili, 2018). Insights from this article can help policy makers understand the issues associated with the rapid development of digital financial services, its delivery to the poor and the associated risks. Four, the discussion in this article adds to the development finance literature that seek ways to reduce poverty in poor economies (see, Allen et al, 2016, Ozili, 2020a). Four, the discussion in this article also contributes to the few and emerging literature that examine the role of technological innovation in financial services (Beck and Frame, 2018; Fostel and Geanakoplos, 2016; Silber, 1983). Insights from the discussions in this article can improve our understanding of the functions of digital finance providers, and can also help regulators understand the relationship between Fintech, digital finance and financial inclusion. Finally, the ideas in this article calls for more collaborative research among academics and policy makers to better understand the relationship between digital finance and development finance as well as the alternative models and perspectives in this area.

The rest of the paper is structured as follows. Section 2 discuss the turn from micro-finance to digitalfinance. Section 3 examine the link between digital finance and development outcomes. Section 4 discuss the risks to poor people in a digital financial system. Section 5 discuss whether digital finance makes a good business sense. Section 6 discuss some ideas for de-risking digital finance. Section 7 provide a possible alternative to the digital finance and microfinance architecture. Section 8 concludes.

\section{The transition to digital finance}

\subsection{Microfinance after the global financial crisis}

"Modern microfinance began in the 1970s as a way to provide loans to small businesses and poor individuals that cannot access credit from formal financial institutions" (Mader, 2018, p.3). The World Bank, who is a major funder, integrated microfinance into its Structural Adjustment Programs (SAP) for developing countries and it became a global development finance tool. Microfinance witnessed huge success in some countries like Singapore and India, and the global microfinance industry also witnessed significant growth in gross loan outstanding and significant increase in the number of borrowers (Butcher and Galbraith, 2019). But, in the last five years, developed countries have begun to abandon the microfinance model and some developing countries have reduced the number of microfinance banks 
due to its many problems. Mader (2018) notes that the microfinance movement has come under tremendous criticism in the post-2008 era, after the global financial crisis, for their high interest rates around 35 percent on average (The Economist 2014), excessive focus on credit over other financial services (Mader 2015: 33-34), failing to reduce poverty levels (Duvendack et al. 2011, Stewart et al. 2012), failure to empower women (Fraser 2009, Karim 2011), driving over-indebtedness (Guérin et al. 2015), excessive spending on fixed costs with little left to give out as loans to small businesses and individuals, and failure to educate micro-borrowers on the implication of loan default if they default in repaying the loans granted to them, etc. These criticisms of microfinance are serious.

For instance, in Latin America, Butcher and Galbraith (2019) show that the microfinance sector provides an environment suitable for Ponzi schemes or Ponzi-type dynamics, the misrepresentation of financial and operating performance, concentration in unregulated markets and areas most conducive to accounting fraud, non-transparency and secrecy, dubious accounting methods, lobbying in favor of deregulation, executive use of the company resources for personal gain, excessive risk taking at the expense of investors' capital, and the inevitable collapse of many microfinance institutions, among others. In South Africa, Bateman (2019) show that South Africa adopted the US model of microcredit. After adopting the U.S. microcredit model, the microcredit initiatives that were introduced in South Africa benefited only a tiny financial elite working within and around the microcredit sector, whilst simultaneously destroying other important pillars of the economy and society (Bateman, 2019).

\subsection{The turn from micro-finance to digital-finance}

The criticisms against microfinance institutions in the post-2008 era led to the demand for micro-loans using digital finance platforms in order to bypass the usual fixed costs and bureaucracy associated with obtaining micro-loans from microfinance institutions. Some microfinance institutions have begun to use digital finance platforms to give micro-loans to poor borrowers, and poor borrowers can now use their mobile phone or computers to find available credit on their banking apps. They can choose the type of loan facility they want, and will need to apply for the loan. But credit being available does not mean it is easily accessible if borrowers need to be physically present in the lending institution to fill some documentation in order to access the loans which they have requested for on their digital finance apps. A good digital finance system is one that do not require the customer to be physically present to apply for a loan, to obtain the loan, make transfers, pay a bill or to access an overdraft facility. Only few countries have a personal banking system that do not require borrowers to be physically present to receive the loans they requested for.

Ideally, using digital finance in micro-financing should eliminate the need for borrowers to visit the microfinance institution to fill some paperwork which is a requirement for loans to be disbursed to borrowers. Moreover, even when loans are accessible through apps and do not require borrowers to be physically present at the bank, it still does not make loans cheaper for poor borrowers rather loans are still expensive for poor borrowers who are inherently risky since they do not have much money. For this reason, there is the argument that the switch from micro-financing to digital-financing does not guarantee that poor individuals and small businesses will receive loans at low interest rates, making it anti-financial inclusion rather than pro-financial inclusion, for this reason, some critics view digital finance as a rebranded microfinance agenda since it does not guarantee cheaper credit to poor people (Mader, 2018). 


\subsection{Can digital finance fail?}

The World Bank has endorsed digital finance as a pro-financial inclusion tool, and today, most policy discussions on financial inclusion are considered incomplete if digital finance is not emphasized. Digital finance, when it works, can improve access to finance, and can help to by-pass the structural problems that hinder access to finance in developing countries. But, can digital finance fail to deliver on its promise? If no, why? If yes, do the promoters of digital finance emphasize its potential to fail with the same fervor they use in promoting its positive benefits? These are questions to reflect on!

Let's consider a real-life example. In 2018, the VISA payment system technology collapsed completely across Europe on the $1^{\text {st }}$ of June, 2018. ${ }^{3}$ On that day, Visa debit cards across Europe were declined when customers used VisaCards to pay for goods and services. Also, customers that do not use VISA cards were unable to make purchases because the VISA network also provided payment system infrastructure for other card issuers that were used in many shops and financial institutions in European countries. Customers in the UK were forced to abandon their shopping or go look for non-VISA cash machines to find cash to pay for purchased items. Even the VISA-linked ATM cash machines stopped working and this caused chaos in European countries. See footnote 1 for more on the European digital financial system crash. This example shows that digital finance can fail.

\subsection{The dangerous assumption}

Digital finance (or financial technology) operates under some subtle assumptions - the most significant one is the assumption that technology is neutral to all kinds of people (Feenberg, 2012). This assumption is flawed because we know that technology is not neutral to everybody particularly poor and uneducated people. Consider the case of uneducated and educated people. Educated people can use financial technology to their advantage because they understand the risks associated with using financial technology and they know how to minimize their exposure to the risks associated with using financial technology. In contrast, uneducated people are unable to use technology to their advantage either because they are not interested in using any financial technology or because they do not know how to use financial technology, and even when they are taught how to use specific financial technology by the promoters of the technology, these uneducated group of people may not be informed about the risks associated with using such financial technology. This example demonstrate why technology is not neutral to all people. Let's also consider the case of poor people. Digital finance or financial technology is not neutral to poor people because the transaction costs associated with using digital finance products or apps to perform financial transactions may be high for poor individuals compared to rich people.

\subsection{Current realities in the digital finance industry}

\subsubsection{New practices}

\footnotetext{
${ }^{3}$ See the link for more on this:

The Sun: https://www.thesun.co.uk/money/6430640/visa-down-network-crashes-uk-europe-card-payments/ The Guardian: https://www.theguardian.com/world/live/2018/jun/01/visa-outage-payment-chaos-after-cardnetwork-crashes-live-updates
} 
Digital finance will invite new players, major and powerful players into the digital finance ecosystem. These players will include formal financial institutions, technology corporations, telecommunication corporations, shadow lenders, and the general public (Mader, 2018 p.4). Some new practices that will emerge include: Fintech companies providing micro loans to poor borrowers, large Fintech companies acquiring formal banking licenses, and increased Fintech-microfinance partnerships (Mader, 2018). Digital finance will also bring online payday lenders, large banks, technology firms, mobile network operators, credit card companies, discount card companies, mutual fund companies and pension fund companies, into the broader financial system which would make the financial system bigger, more complex and more volatile. Consequently, stability in the digital finance ecosystem will depend on the interlinkages between financial sector agents, communication systems and technology systems because digital finance cannot stand alone as a distinct and free-standing industry.

These new practices in the digital finance ecosystem will blur the line between user convenience and user's exposure to information risk, financial risk and technology risk. While digital finance can provide convenience to users, the risk of technological or system failure and human error is also high. The role of governments will also change in the digital finance era. Governments will have to decide on whether to deregulate the financial technology industry (Ozili, 2019), impose regulations to monitor the activities of Fintech companies (Treleaven, 2015), create space for Fintech companies to grow in a regulatory sandbox (Bromberg et al., 2017), or use Regtech technologies to monitor the developments in the digital finance ecosystem.

\subsubsection{New products: blockchain}

Blockchain technology is a decentralized distributed ledger that records the transactions linked to digital assets. Blockchain can enable financial institutions, all of which are currently investing in technology, to do more with less, streamline their businesses, and reduce risk in the process (Tapscott and Tapscott, 2017). Blockchain can also reduce transaction costs among all participants in the economy, and can support models of peer-to-peer mass collaboration that could make many of the existing traditional organizational forms redundant (Tapscott and Tapscott, 2017). Through blockchain, companies of any size will be able to raise money in a peer-to-peer way through global distributed share offerings (Tapscott and Tapscott, 2017). While financial firms, consultants, healthcare providers, and others are seeking ways to integrate blockchain into their processes, the concept of block-chain is still a strange concept to many individuals and is out of reach for poor people. And even if ordinary people understand the "what" of blockchain, understanding why it should be used and what problems it can solve remains unclear to them. And there is yet no clear benefit of blockchain to poor people (Garzik and Donnelly, 2018).

\subsubsection{New ideas, new ideology and new problems}

There is the belief or idea that modern digital finance blends technology with contemporary sustainable development goals. Statements like: "digital finance: empowering the poor via new technologies" taken from a headline World Bank publication (World Bank, 2014) - shows the blending of finance with technology and development finance. Also, statements like "digital finance is a powerful means to expand access beyond financial services to other sectors, including agriculture, transportation, water, health, education, and clean energy." ${ }^{-}$- shows that the World Bank and related agencies view

\footnotetext{
${ }^{4}$ http://www.worldbank.org/en/news/feature/2014/04/10/digital-finance-empowering-poor-new-technologies
} 
digital finance as a significant catalyst to promote inclusive growth across multiple sectors. This belief system or ideology makes sense only if digital finance improves the level of financial inclusion by ensuring that the excluded population have access to financial services through digital devices which can enable them participate in the formal financial sector.

One issue with digital finance ideologies is that they reinforce the inequalities which financial institutions create. Financial institutions create inequalities in the formal financial sector by providing specialized financial products and services to customers with different income levels, which are often categorized as high net-worth individuals (HNIs), politically-exposed persons (PEPs) and no-incomeno-job-applicants (NINJA). Using digital finance products to deliver basic financial services does not reduce or eliminate the inequalities created by financial institutions rather digital finance products or systems reinforce the existing inequalities in the financial sector. Ignoring how digital finance creates inequality or amplify existing inequality in the financial sector can lead to greater financial exclusion, and financial institutions can exploit this inequality in ways that help them achieve their own business objectives at the expense of poor people.

Different players in the digital finance ecosystem set their own rules for profit seeking motives. For instance, consider a bank customer or depositor that has little money in his or her bank account with a daily average account balance of about $\$ 10$, and the transaction cost is $\$ 5$ for a specific transaction. The poor customer won't be willing to perform this transaction through the digital bank app because the transaction cost of using the digital finance app or platform is high, and in some cases, might exceed the customer's current bank balances (assuming there are other applicable bank charges). In some geography, some banks place limits (for example, minimum deposit thresholds) as a pre-condition to use certain digital banking applications to discourage poor and low-income customers from using such digital financial products. For instance, a bank can require customers to have at least a $\$ 500$ account balance as a pre-condition to qualify to use specific banking products that are linked to digital finance apps of the bank. Customers that do not have the ability to maintain a $\$ 500$ minimum account balance will not be allowed to use the digital bank app.

The point here is that we need to pay special attention to how the players in the formal financial sector create inequality in the delivery of digital financial services while claiming to promote financial inclusion. Bringing the poorest into the financial system through digital finance can exacerbate existing inequality and produce new forms of exclusion (Meagher, 2015). It can expose the poorest to systematic risks in the digital finance ecosystem, and there is still no evidence to show that the poorest population will get cheaper funds or a 'fair deal' when they are brought into the digital financial system (Mader, 2018). In fact, poor people generally get lower-quality services at higher prices (Mader, 2018).

\subsubsection{New theories of change}

Digital finance changes the expectation of how poor people should benefit from engaging with finance. The original 'branch-banking theory of change' reduced poverty levels by allowing individuals and businesses to obtain micro loans by visiting the nearest bank branch to obtain funds for consumption purposes and for entrepreneurial activities (Mader, 2018; Benston, 1965; Evanoff, 1988). By contrast, the 'digital finance theory of change' believes that the most significant way to increase access to finance is to reduce the customer-bank interface by providing financial services to bank customers remotely using digital finance products and platforms (see Ozili, 2018). Reducing the number of interface between a borrower and the bank is not only desirable, it is also an important indicator of how successful a financial innovation is (Ozili, 2018). Under the digital finance theory of change, banks will be able to 
reduce the cost of loan documentation and filing by automating the documentation process, and the reduced cost will improve banks' profitability.

Another theory of change relating to digital finance is the systems theory of financial inclusion (Ozili, 2020b). The theory argues that all financial inclusion outcomes are achieved through existing systems and sub-systems, such as the digital finance infrastructure and the payment system infrastructure which are part of the larger financial system. The theory further argues that a significant change in the subsystem (one part of the system) can significantly affect financial inclusion outcomes while a significant change at the full system level does not necessarily lead to a change in the existing sub-systems because a change in the sub-system must be done at the sub-system level (Ozili, 2020b). The implication of the theory for digital finance is that any change that needs to be introduced into the digital finance infrastructure must be done at the operational level, not at the user level (such as, telling users to stop using a digital platform or telling users to be careful when using a digital finance product due to risk). The emphasis on "a change in the sub-system must be done at the sub-system level" supports the argument that the digital finance infrastructure should be de-risk at the operational level. The theory also suggests that financial inclusion will improve the workings of the sub-systems it rely on. This means that existing digital finance systems will evolve over time to accommodate changes in financial inclusion objectives and outcomes. The merits of the systems theory of financial inclusion is that it recognizes the role of existing economic, financial and social systems or structures in a country in promoting financial inclusion, and it considers how financial inclusion outcomes are affected by the interrelationship among the sub-systems that financial inclusion relies on.

\subsubsection{Technology versus decision making}

Digital finance is also an invitation to live by technology. Digital finance will change how people engage with technology. Bringing the poor into the digital finance space will change how poor people live their lives and will change how they make financial decisions. It is still unknown whether the changes will improve or worsen the financial well-being of the poorest population. Also, the convenience and swiftness that digital finance technology brings can prevent users from spending quality time when making important personal finance decisions. With digital finance being about making transfers and payments through digital devices linked to some payment systems, people now spend less time in making personal finance decisions than before. Before now, bank customers had to carefully make financial decisions before going to the bank, and then visit the bank to carry out transactions based on their decisions. But now, there is no need to visit banks to perform basic transactions due to the prevalence of click-and-pay digital apps.

\subsubsection{Some reflections on current realities}

Digital finance does not promote "poverty finance" since it offers the same risk to the poor and the rich. Both the poor and rich are exposed to fraud risk, high transaction costs and system failures. Poor people are more likely to suffer because most digital finance platforms require internet connection which may be too costly for poor people. Therefore, promoting digital finance as a pro-development finance tool for poverty alleviation is indeed dangerous because (i) the rich are better able to mitigate or use insurance to transfer the risks associated with using digital finance platforms while the poor do not have enough money to insure themselves from the risks associated with using digital financial platforms. Secondly, the digital finance agenda will attract profit-seeking companies and other powerful capitalists that will support development projects as long as it does not negatively affect their expected profit levels. In other words, profit-seeking corporations and capitalists often support development projects 
that have a positive net present value (i.e., NPV $\geq 0$ ). Thus, it is reasonable to conclude that the current digital finance agenda is a private sector engineered tool to serve the interest of users and the promoters.

\section{Digital finance and development outcomes}

\subsection{Review of some reports}

Proponents of digital finance claim that individuals and poor people will benefit from digital financial services. They claim that digital finance will empower and transform the lives of poor people with digital finance. What is the basis for these great expectations?

For instance, the review of a report on digital finance from the Bill and Melinda Gates Foundation assert that:

"Our strategy is aimed at...helping to drive the development of digital payment systems that can help spread the use of digital financial services quickly, advancing gender equality to ensure women share in the benefits of financial inclusion, and supporting the development of national and regional strategies that accelerate progress for the poor and provide exemplar models", (Bill and Mellinda Gates Foundation ${ }^{5}$ )

And they further add that:

"To achieve these objectives, we work with partners around the world to align on common principles for digital financial inclusion and support policymakers as they work to develop policies and regulations that facilitate growth in digital financial services and provide oversight and accountability."

These two statements do not show a direct link between digital finance and the poorest population. These statements can be criticized on two grounds because (i) introducing a digital payment system to a community and attempting to spread the use of digital financial services in that community is indeed a great idea but there is no guarantee that poor people will be interested in digital technology, and because (ii) poor people want money, not technology: they need money to take care of their families they don't need technology to feed their families.

On the other hand, a more reasonable statement that links digital finance to development outcomes is a statement by the World Economic Forum (WEF) which reads:

"Formal financial services, including those accessed through a phone, are connecting people to economic opportunities and helping them escape poverty. Without a savings account, it can be difficult for poor people to put away money for future investments in education or business. Without insurance, a crop failure can push farmers and their families into destitution." (Hess \& Klapper, 2016; WEF) ${ }^{6}$.

\footnotetext{
${ }^{5}$ https://www.gatesfoundation.org/What-We-Do/Global-Growth-and-Opportunity/Financial-Services-for-thePoor

${ }^{6}$ https://www.weforum.org/agenda/2016/12/people-are-escaping-poverty-with-the-help-of-digital-finance-howshould-we-measure-that-1/
} 
"Today, a mobile phone can be used by women in Hyderabad to pay their gas bill, by young people in Hanoi to quickly send money to their parents living in a rural village, and by farmers in Kampala to receive payments for the sale of coffee beans."

The two statements from the WEF above contain at least a valid benefit of digital finance for people, but as you can see it does not emphasis 'poor people'. Rather, it is the children of poor families that send money to their poor parents. Advocates of digital finance like to invoke these kind of statements and reports as evidence that digital finance benefits poor people but it clearly does not improve the welfare of poor people. These statements or reports fail to point out that digital finance only benefits the people that are already in the formal financial system which implies that the excluded population do not enjoy the benefit of digital finance.

Another report from Klapper (2018) reads:

“...Mobile money accounts don't just make life easier. They can help prevent people from falling into poverty by softening the impact of sudden expenses. For example, medical bills push millions of people into poverty annually. When a villager gets sick, she can use mobile remittances to gather money from faraway relatives....Research suggests that people with mobile money accounts get more money when an emergency hits, from a wider social and geographic network of friends, thereby helping them make ends meet during a crisis..."

The statement above shows that there is the assumption that digital finance can uplift the poor from poverty by using account-based digital payments in distributing social benefits to poor people through digital channels instead of cash, which will reduce corruption, increase efficiency and help recipients build savings (Klapper, 2018). This idea is logical only that it ignores two major risks: one, the possibility that digital cash transfers may not reach poor recipients when they need it, and two, lack of protection for vulnerable and poor users of mobile money or other digital channels.

There is also the assumption that digital finance can uplift poor countries from their poverty and that advanced countries have used digital finance to eliminate poverty. This assumption is false because despite the wide use of digital finance in advanced countries, it has not eliminated poverty in advanced countries (Charlton, 2018). There is evidence that in advanced countries where there are advanced digital finance systems, large amount of credit is granted more quickly to middle-income, high-income individuals and enterprises, not necessarily to the poorest people (Lipton, 1977; Yunus, 2007), which leaves poor people behind. Bateman et al (2019) criticize the claim that digital finance or fin-tech is instrumental in reducing poverty level in Africa. They show that financial technologies such as M-Pesa is problematic and does not alleviate poverty in Kenya or Africa.

Some proponents of digital finance also bring up the macroeconomic argument in support of digital finance for the poor (e.g. Li et al, 2020; Kshetri, 2017; Ghosh, 2016). The "macro" argument claim that providing digital financial services would increase economic output through increased financial intermediation which will lead to economic growth for the benefit of all including the poor; but the evidence for this, is still inconclusive or of questionable relevance to the development finance debate. For instance, Li et al (2020) show that digital finance is positively correlated with increased consumption expenditure such as food, clothing, house maintenance, medical care, and education and entertainment expenditures. They find that digital finance mainly promoted recurring household expenditures rather than the non-recurring expenditures for households. But the survey in Li et al (2020)'s study was not conducted using data for poor people, which suggest that such findings may not 
be generalized to poor people who mostly do not have enough money to spend on entertainment or expensive education.

Others criticize the ability of digital finance to spur development citing cultural differences and regulatory challenges. Zetsche et al (2017) argue that cultural differences in the population may prevent people from using digital finance technology to the fullest in ways that would improve their welfare for local development. They also argue that the speed at which digital finance (or financial technology) is growing is of concern to many people and there are fears that regulators may not be able to fully monitor and control the digital finance ecosystem. Another study Ozili (2018) identify 'discrimination' in the provision and marketing of digital finance products as a barrier that makes it difficult for digital finance to spur development in the interest of poor people. Ozili (2018) point out that the providers of digital finance services can discriminately use a more aggressive marketing tactic to persuade high-and-middle income customers to use a new or existing digital finance platform or infrastructure and use a less aggressive marketing tactic to persuade poor customers to use new or existing digital platforms or infrastructure if they believe the latter cannot afford the associated fees, thereby leading to lower use of digital finance products by poor people.

\section{Risks to poor people in a digital financial system}

Here, I argue that the poor, who are economically vulnerable, should not be brought into the digital finance ecosystem until the digital finance ecosystem has been de-risked and is safe for the poor to be brought in. Bringing the poorest people into the risky digital financial system can have unintended consequences. Below are some consequences.

\subsection{Fraud risk:}

Firstly, bringing poor people into the digital finance ecosystem will expose them to fraud risk, especially those related to data theft such as stealing credit card and debit card information. It can be difficult to verify that the individuals entering their personal information into an online payment system are who they say they are since there may be no personal identification protocol such as request for picture or signature identification.

\subsection{Access problems due to lack of internet connectivity:}

Secondly, lack of internet connectivity is a risk that poor people face. Poor people will need the internet to access their bank account. If the internet connection fails and they cannot afford internet subscription, they won't be able to access their bank account.

\section{3: Systematic risks, technology and infrastructure risks:}

Poor people also face two key risks: (i) systematic risks in the financial system and (ii) technology and infrastructure risks arising from the use of financial technology. The systematic risks in the financial system relate to issues such as high interest rates, high transaction costs, banks placing limits on daily withdrawals, etc., while technology and infrastructure risks relate to issues such as power failure, internet connection failure, loss of records, dysfunctional software, unresponsive call center agents, etc.

\subsection{Loss of trust:}

The most common consequences of the risks in the digital financial system is loss of trust which lowers the use of digital technology for financial transactions. This begins from awareness to registration, then from registration to first use, and from first use to regular use; and then poor clients lose funds due to 
increased transaction charges. The poor clients lose trust in the financial system and therefore reduce the use of the service; and might not use the service anymore (Arenaza, 2014).

4.5. No clarity on who protects the poor from digital risk.

There are many actors in the digital finance value chain but responsibility for risk associated with digital finance is often not clearly assigned. There is no clarity on who is responsible for protecting poor clients from risks associated with using digital finance. It is not clear whether the bank, financial institution, government, Telcos, third party provider, the regulator or self-regulation will protect the poor from digital finance risk. The involvement of these many actors along the value chain makes the digital financial system complex and blurs the line on who should take responsibility for protecting poor clients (Arenaza, 2014).

\subsection{Transferring old risks to new customers}

Digital finance does not create major new risks beyond those that already exist in the traditional payment system and in the financial system at large. The most important change occurring in today's digital financial system is the transfer of old (or existing) risk to new customers - many of whom are poor people (Bill and Melinda Gates Foundation, 2015). Old risks are being transferred to new players in the digital payments value chain who lack the resources to manage such risk, and when those risks materialize, their customers suffer - especially the poor ones.

Other risks to poor people include: the inability to transact due to network downtime or service unreliability, insufficient agents, complex user interfaces and payment processes, ATM liquidity, poor recourse mechanism, no recourse mechanism, and fraud that target the poor recipient. To summarize, these risk events, when they materialize, can be frustrating to both the high-income, low-income and poor users of digital financial services. Poor people will be the most affected because they do not have enough money to insure themselves against financial risks in the financial system. This is why I argue that the digital finance ecosystem should be de-risked before bringing poor people into the financial system.

\section{Digital finance and good business sense}

Digital finance is a viable business worth pursuing in its own right. Financial technology companies like Stripe, Verve and MasterCard have signaled their interest in digital finance as a business opportunity and welfare enhancing tool. For digital finance to make a good business sense, the technologists, bankers and financial sector players must succeed at offering quality services at affordable prices to make profit in ways that encourage clients to use them. While most companies are succeeding in this area, there is still the problem of selective clientele (Mader, 2018). Most private sector companies that offer digital finance often cherry-pick its offering of digital financial services to selected clienteles. They target urban locations with a high number of employed and educated population (Mader, 2018). Moreover, the selective offering of digital financial services has led to suggestions that the government should be directly involved in the digital financial services ecosystem to prevent private players from isolating the poor (Mader, 2018). However, there is no guarantee that the selective clientele problem will be eliminated if the government become a major player in the digital finance ecosystem.

Also, it is important to mention that many governments are unwilling to invest a significant amount of public funds in the digital finance business because policy makers believe that full efficiency can be 
attained only when private money is used to fund technology projects. Therefore, there are doubts about whether governments should participate in digital finance delivery or not. Another idea is the proposition that a government should initiate the digital finance business and deliver it to private companies to operate and manage on the government's behalf. In this scenario, the government can provide a supportive environment that makes finance available to everyone through their mobile phones and some regulation may be needed to achieve this. The government may also consider channeling welfare payments to citizens through digital finance providers, and the digital finance providers can make digital transfers to the recipients of welfare payments, and this can bring more poor and lowincome individuals into the financial sector, and reduce cost per transaction (see Allen et al. 2016; UNCTAD 2014: 17; Mader, 2018). To sum up, digital finance makes a good business sense but the profitability of the digital finance business cannot be sustained in the long term without government support either through direct public investment or through reduced regulations or a combination of both.

\section{De-risking digital finance}

Some studies show that people can withdraw from using digital finance products if it is too risky. Also, providers of digital finance products can refuse to deliver financial services to high risk communities. For instance, Ozili (2018) show that providers of digital financial services can withdraw or discontinue the provision of specific digital finance services to high-risk rural areas. Bill and Melinda Gates Foundation (2015) state that the largest insolvency risk and liquidity risk associated with digital payments is the risk that a 'run on the telco' or 'run on the agent network' may occur and consumers will be unable to access their funds through their mobile phones, bank cards or bank apps, and that such an event would likely be country-specific or may have cross-border dimensions. Also, Königsheim, Lukas and Nöth (2017) show that lack of financial knowledge and risk intolerance reduces the likelihood to use digital financial services. Also, RFF (2017) show that digital finance creates cybersecurity risks that can lead to loss of consumer data and identify theft which can inflict financial harm to customers including poor customers, in addition, it can put providers at risk and can undermine public confidence in the digital finance ecosystem.

There is need to de-risk the digital financial system especially digital finance products and platforms. The reason for de-risking digital finance is not just because people will be dependent on mobile phones or computers for financial transactions, it's not just because poor people have little money, and it's not even because cyber criminals can exploit digital technology to steal poor people's money; rather, it is primarily because life, risk and technology are getting more intimate than ever and a lot of poor people are coming to the financial sector who may not have the capability and resources to protect themselves from risks in the financial sector when they materialize which can lead to severe financial losses, and such losses can lead to anxiety, depression, frustration, mental complications and even loss of life to vulnerable individuals and poor people. Policy makers should pressure technologists to de-risk the digital finance products and platforms they extend to poor people because the recent interconnectedness between life, risk and technology will have a more serious effect on poor people than other income groups in the years to come.

Finally, digital finance can be de-risked for poor people in two ways - at the operational level and at the agent level as shown in table 1 


\begin{tabular}{|c|c|c|}
\hline \multicolumn{3}{|c|}{ Table 1: De-risking digital finance } \\
\hline $\mathrm{S} / \mathrm{N}$ & Agent-level & Operational-level \\
\hline 1 & $\begin{array}{l}\text { Agents should conduct business fairly with } \\
\text { poor clients }\end{array}$ & Strengthen data protection and security \\
\hline 2 & $\begin{array}{l}\text { Agent should be well-trained and should know } \\
\text { how to perform the transaction on behalf of } \\
\text { poor clients. }\end{array}$ & Prioritize data privacy \\
\hline 3 & $\begin{array}{l}\text { Agents should provide adequate information } \\
\text { to help poor clients make informed decisions }\end{array}$ & $\begin{array}{l}\text { Place controls to prevent loss of funds, and } \\
\text { controls that minimize fraud on small } \\
\text { accounts belonging to poor clients }\end{array}$ \\
\hline 4 & Use responsible pricing & $\begin{array}{l}\text { Provide sufficient transparency and } \\
\text { disclosure of information }\end{array}$ \\
\hline 5 & & $\begin{array}{l}\text { Install controls that prevent unauthorized } \\
\text { fees and unfair pricing to poor clients }\end{array}$ \\
\hline 6 & & $\begin{array}{l}\text { Operators should conduct business fairly } \\
\text { with poor clients }\end{array}$ \\
\hline 7 & & $\begin{array}{l}\text { Use appropriate product design and } \\
\text { delivery }\end{array}$ \\
\hline 8 & & $\begin{array}{l}\text { Provide adequate care for poor client using } \\
\text { client support, client helpdesk, dispute } \\
\text { resolution, and complaint mechanisms }\end{array}$ \\
\hline 9 & & $\begin{array}{l}\text { Information providers should provide } \\
\text { adequate information to help poor clients } \\
\text { make informed decisions }\end{array}$ \\
\hline
\end{tabular}

\section{Possible alternatives to the digital finance and microfinance architecture}

If the digital financial system cannot be de-risked, then we need to find other alternatives that pose little or no risk to poor people. One possible alternative is to strengthen the existing informal systems and networks of finance which poor people rely on for food and subsistence, especially poor people in remote communities who are outside the formal financial sector. In the microfinance era, governments attempted to (i) use the presence of microfinance institutions to frustrate and dismantle the informal financial system in communities, or (ii) to formalize all informal networks of finance by integrating them into the formal financial system through microfinance institutions, but they failed to achieve this because the informal financial system and informal networks of finance in many communities were established on strong social ties with poor members of the communities and such social ties cannot be broken easily. This is the major reason why the informal financial sector has continued to flourish today despite the presence of many Fintech businesses and digital finance providers in the business environment. In fact, the informal financial sector has survived the globalization era, the microfinance era and has survived several episodes of financial crises, which suggests that the informal financial system play an important role in the lives of poor people, and for this reason, the benefits of the informal systems and networks of finance should be maximized to the fullest. Ojong and Obeng-Odoom (2017) show that the informal network of finance in Cameroon was able to bridge the gap between lending and 
saving activities, and people were able to access the formal financial system through existing informal networks of finance, and therefore, there was no need to formalize the informal institutions and networks in Cameroun.

\section{Conclusion}

This paper examined the delivery of digital finance to poor people, and contest the claim that digital finance is pro-poor and pro-development. It argues that the transition from microfinance to digital finance has benefits but the risks are significant for poor people. It debunks the claim that technology is neutral for everybody and argue that technology is not neutral for everybody especially poor people. It shows that digital finance reinforces the existing inequality in the financial system which worsen the welfare of poor people. It also showed that the assumption of poor people benefiting directly from digital finance is weak. Apart from improved money management through digital finance apps, there are no other positive effects of digital finance to the poorest people. The article also showed that bringing the poorest into the financial system will expose them to risks in the formal financial system. Some risk facing poor people include fraud risk, lack of access to internet connectivity, systematic risks, technology and infrastructure risks, loss of trust, no clarity on who protects the poor from digital risk, transferring old risks to new customers. Furthermore, digital finance makes a good business case only with government support. Finally, the article suggests ways to de-risk the digital finance infrastructure. Digital technology offered to poor people should bear little or no risk for maximum impact on the poor. Policy makers should press for more robust evidence for the developmental and poverty-reducing impact of digital finance while at the same time giving greater consideration to alternative povertyfinance interventions.

Here are four points to remember. First, the evidence for, or against, digital finance needs to be strengthened. Secondly, much attention should be paid to the limitations and downsides of digital finance. Thirdly, financial sector regulators should put in much effort to de-risk the financial system before bringing the poor to the formal financial sector. Four, digital finance is just another business opportunity for banks and corporate capitalists who can exploit it at the expense of poor people, hence, government intervention through regulation may be needed. Future research should explore whether financial inclusion is really 'poverty-reducing' and 'pro-poor'. Future studies can also explore whether full financial inclusion can be achieved without direct government support or public funding.

\section{Reference}

Allen, F., Demirgüç-Kunt, A., Klapper, L., \& Peria, M. S. M. (2016). The foundations of financial inclusion: Understanding ownership and use of formal accounts. Journal of Financial Intermediation, 27, 1-30.

Arenaza, S. (2014). Potential risks to clients when using Digital Financial Services. In Collaboration between the Smart Campaign and Accion Channels and Technology. Massachusetts, United States 
Banks, E. (2001). e-Finance: the electronic revolution in financial services. John Wiley \& Sons, Inc.

Barbesino, P., Camerani, R., \& Gaudino, A. (2005). Digital finance in Europe: Competitive dynamics and online behaviour. Journal of Financial Services Marketing, 9(4), 329-343.

Barr, N. (2012). Economics of the welfare state. Oxford university press.

Bateman, M. (2019). South Africa's post-apartheid microcredit experiment: moving from stateenforced to market-enforced exploitation. In Forum for Social Economics (Vol. 48, No. 1, pp. 69-97). Routledge.

Bateman, M., Duvendack, M., \& Loubere, N. (2019). Is fin-tech the new panacea for poverty alleviation and local development? Contesting Suri and Jack's M-Pesa findings published in Science. Review of African Political Economy, 46(161), 480-495.

Benston, G. J. (1965). Branch banking and economies of scale. The Journal of Finance, 20(2), 312331.

Beck, T., \& Frame, W. S. (2018). Technological change, financial innovation, and economic development. In Handbook of Finance and Development. Edward Elgar Publishing.

Benhabib, J., Bisin, A., \& Jackson, M. O. (Eds.). (2010). Handbook of social economics. Elsevier.

Bill and Melinda Gates Foundation (2015). Assessing risk in digital payments. Special Report, Financial Services for the Poor, Bill and Melinda Gates Foundation, February 2015. Available at: https://docs.gatesfoundation.org/documents/Assessing\%20risk\%20in\%20digital\%20payments\%20FS P.pdf

Bromberg, L., Godwin, A., \& Ramsay, I. (2017). Fintech sandboxes: Achieving a balance between regulation and innovation. Journal of Banking and Finance Law and Practice, 28(4), 314-336.

Brown, M., Guin, B., \& Kirschenmann, K. (2015). Microfinance banks and financial inclusion. Review of Finance, 20(3), 907-946.

Butcher, W., \& Galbraith, J. (2019, January). Microfinance control fraud in Latin America. In Forum for Social Economics (Vol. 48, No. 1, pp. 98-120). Routledge.

Cabraal, A., Russell, R., \& Singh, S. (2006, October). Microfinance: Development as freedom. In Financial Literacy, Banking and Identity Conference (pp. 25-26). Melbourne: RMIT University.

Charlton, E. (2018). Why rich countries are seeing more poverty. World Economic Forum, November 20. Available at: https://www.weforum.org/agenda/2018/11/why-rich-countries-are-seeing-morepoverty/

Domeher, D., Frimpong, J. M., \& Appiah, T. (2014). Adoption of financial innovation in the Ghanaian banking industry. African review of Economics and Finance, 6(2), 88-114.

Duvendack, M; Palmer-Jones, R.; Copestake, J.G.; Hooper, L.; Loke, Y. and Rao, N. (2011) What is 
the Evidence of the Impact of Microfinance on the Well-Being of Poor People? Systematic Review, London: EPPI-Centre, University of London.

Evanoff, D. D. (1988). Branch banking and service accessibility. Journal of Money, Credit and Banking, 20(2), 191-202.

Feenberg, A. (2012). Questioning technology. Routledge.

Figueiredo, M., Prado, P., \& Kramer, M. (2012). Overcoming poverty through digital inclusion. IT Professional, 14(3), 6-10.

Fraser, Nancy. 2009. Feminism, capitalism, and the cunning of history. New Left Review 56:97-117.

Fostel, A., \& Geanakoplos, J. (2016). Financial innovation, collateral, and investment. American Economic Journal: Macroeconomics, 8(1), 242-84.

Gabor, D., \& Brooks, S. (2017). The digital revolution in financial inclusion: international development in the fintech era. New Political Economy, 22(4), 423-436.

Garzik, J., \& Donnelly, J. C. (2018). Blockchain 101: an introduction to the future. In Handbook of Blockchain, Digital Finance, and Inclusion, Volume 2 (pp. 179-186). Academic Press.

Ghosh, S. (2016). Does mobile telephony spur growth? Evidence from Indian states. Telecommunications Policy, 40(10-11), 1020-1031.

Guérin, I.; Labie, M. and Servet, J. (2015) The Crises of Microcredit. London: Zed Books

Gwama, M. (2014). Explaining weak financial development in Africa. African Review of Economics and Finance, 6(2), 69-87.

Hakim, C. (2012). Research Design: Succesful Designs for Social Economics Research. Routledge.

Hellmich, S. N. (2017, January). What is socioeconomics? An overview of theories, methods, and themes in the field. In Forum for Social Economics (Vol. 46, No. 1, pp. 3-25). Routledge.

Hembruff, J., \& Soederberg, S. (2019, January). Debtfarism and the Violence of Financial Inclusion: The Case of the Payday Lending Industry. In Forum for Social Economics (Vol. 48, No. 1, pp. 49-68). Routledge.

Hu, B., \& Zheng, L. (2016). Digital finance: Definition, models, risk, and regulation. In Development of China's Financial Supervision and Regulation (pp. 31-58). Palgrave Macmillan, New York. Karim, L. (2011) Microfinance and its Discontents: Women in Debt in Bangladesh. Minneapolis, MN: University of Minnesota Press.

Klapper, L. (2018). How mobile money can help reduce poverty. ITU News. August 9. Avaialble at: https://news.itu.int/mobile-money-poverty/

Königsheim, C., Lukas, M., \& Nöth, M. (2017). Financial knowledge, risk preferences, and the demand for digital financial services. Schmalenbach Business Review, 18(4), 343-375. 
Kshetri, N. (2017). Will blockchain emerge as a tool to break the poverty chain in the Global South?. Third World Quarterly, 38(8), 1710-1732.

Lipton, M. (1977). Why poor people stay poor: a study of urban bias in world development. Temple Smith; Australian National University Press.

Mader, P. (2018). Contesting financial inclusion. Development and Change, 49(2), 461-483.

Mader, P., \& Sabrow, S. (2019, January). All Myth and Ceremony? Examining the Causes and Logic of the Mission Shift in Microfinance from Microenterprise Credit to Financial Inclusion. In Forum for Social Economics (Vol. 48, No. 1, pp. 22-48). Routledge.

Meagher, K. (2015) Leaving No One Behind? Informal Economies, Economic Inclusion and Islamic Extremism in Nigeria. Journal of International Development, 27 (6): 835-855.

Ojong, N., \& Obeng-Odoom, F. (2017). Resilience and dynamism of embedded financial transactions in Cameroon. Journal of Economic Issues, 51(1), 181-200.

Ozili, P. K. (2018). Impact of digital finance on financial inclusion and stability. Borsa Istanbul Review, 18(4), 329-340.

Ozili, P. K. (2019). Blockchain Finance: Questions Regulators Ask. Disruptive Innovation in Business and Finance in the Digital World (International Finance Review, Vol. 20), Emerald Publishing Limited, 123-129.

Ozili, P. K. (2020a). Financial Inclusion Research Around the World: A Review. Working Paper.

Ozili, P. K. (2020b). Theories of Financial Inclusion. Available at SSRN 3526548.

RFF (2017). Opportunities and Risks in Digital Financial Services: Protecting Consumer Data and Privacy. Responsible Finance Forum, 8, 27-28. April, Berlin, Germany. Available at: https://responsiblefinanceforum.org/wp-content/uploads/2017/06/RFFVIII-

Opportunities_and_Risks_in_Digital_Financial_Services-

Protecting_Consumer_Data_and_Privacy.pdf

Schotter, A. (2008). The economic theory of social institutions.

Silber, W. L. (1983). The process of financial innovation. The American Economic Review, 73(2), 89-95.

Stewart R., van Rooyen, C., Korth, M., Chereni, A., Rebelo Da Silva, N., \& de Wet, T. (2012). Do micro-credit, micro-savings and micro-leasing serve as effective financial inclusion interventions enabling poor people, and especially women, to engage in meaningful economic opportunities in low- and middle-income countries? A systematic review of the evidence. Technical report, EPPI-Centre, Social Science Research Unit, University of London. 
Tapscott, A., \& Tapscott, D. (2017). How blockchain is changing finance. Harvard Business Review, 1(9), 2-5.

The Economist (2014) 'Poor Service: Tiny Loans are Getting more Expensive', The Economist, 1 February.

Treleaven, P. (2015). Financial regulation of FinTech. Journal of Financial Perspectives, 3(3).

Von Wieser, F. (2013). Social economics. Routledge.

Yunus, M. (2007). Credit for the poor: Poverty as distant history. Harvard International Review, 29(3), 20.

Zetsche, D. A., Buckley, R. P., Arner, D. W., \& Barberis, J. N. (2017). From FinTech to TechFin: The regulatory challenges of data-driven finance. NYUJL \& Bus., 14, 393. 